\title{
Digestion of concentrate and of hay diets in the stomach and intestines of ruminants
}

\author{
1. Sheep
}

\author{
By J. H. TOPPS, * R. N. B. KAY AND E. D. GOODALL \\ Rowett Research Institute, Bucksburn, Aberdeen \\ (Received 20 September 1967-Accepted in December I967)
}

\begin{abstract}
I. The flow of digesta to the abomasum and through the duodenum and terminal ileum was measured over $\mathbf{2 4} \mathrm{h}$ periods in sheep. Pelleted diets of concentrates, principally composed of barley, and of poor-quality hay were given. The seven Scottish Blackface ewes studied were all fitted with rumen cannulas, and in addition two had simple abomasal cannulas, one a re-entrant abomasal cannula, two re-entrant duodenal cannulas, and two re-entrant ileal cannulas.

2. Paper impregnated with chromium sesquioxide was given twice daily by rumen fistula. The amounts of dry matter, starch, cellulose, total nitrogen and energy passing through the abomasum, duodenum and ileum and the amounts excreted in the faeces were measured. The flows of digesta were adjusted to give $100 \%$ recovery of chromium sesquioxide and the extent of digestion in various parts of the alimentary tract was calculated using these adjusted values. Concentrations of glucose in the blood and of volatile fatty acids (VFA) in the rumen were also measured.

3. For the concentrate diet, $69 \%$ of the digestible dry matter disappeared in the stomach (reticulo-rumen, omasum and abomasum), $17 \%$ in the small intestine and $14 \%$ in the large intestine. Values for disappearance of digestible energy were $72 \%$ in the stomach, $23 \%$ in the small intestine and $5 \%$ in the large intestine. Of the $298 \mathrm{~g}$ starch fed daily only $6-35 \mathrm{~g}$ passed through the abomasum or duodenum and only $\mathrm{I}-4 \mathrm{~g}$ reached the terminal ileum. The cellulose in the diet was poorly digested.

4. For the hay diet, $67 \%$ of the digestible dry matter disappeared in the stomach, $22 \%$ in the small intestine and $11 \%$ in the large intestine. Values for disappearance of digestible energy were $81 \%$ in the stomach, $7 \%$ in the small intestine and $12 \%$ in the large intestine. Of the $33 \mathrm{~g}$ of starch consumed daily, from 5 to $\mathrm{I} 3 \mathrm{~g}$ passed through the abomasum or duodenum. The cellulose in the hay was $59 \%$ digestible and virtually all this digestion took place in the stomach.

5. The concentration of VFA and the proportion of propionate in the rumen fiuid, $2.5 \mathrm{~h}$ after feeding, were considerably greater on the concentrate diet than on the hay diet, but diet had little influence on the concentration of blood glucose.

6. 'The importance of the small amount of starch passing to the sheep's small intestine is discussed.
\end{abstract}

The volume and composition of the digesta passing through various sections of the digestive tract of sheep can be measured directly by causing the digesta to flow through re-entrant cannulas inserted into either the duodenum or terminal ileum (Phillipson, I952; Sineshchekov, 1953; Hogan \& Phillipson, I960; Harris \& Phillipson, 1962; Phillips \& Dyck, I964; Goodall \& Kay, 1965; Bruce, Goodall, Kay, Phillipson \& Vowles, I966; Clarke, Ellinger \& Phillipson, I966). The technique has been used to determine the relative amount of digestion which occurs in the sheep's stomach, as a result of fermentative processes, compared with that taking place in the small or large intestine. Most attention has been given to the disappearance of dry matter, organic matter, nitrogen and some minerals.

\footnotetext{
* Present address: School of Agriculture, University of Aberdeen.
} 
Ridges \& Singleton ( 1962 ) carried out similar studies with goats, and recently Porter $\&$ Singleton (1965) have used the technique to examine the passage of carbohydrate from the stomach of a hay-fed goat. They found a complex mixture of polysaccharides in the duodenal digesta but this included very little $\alpha$-linked glucose, equivalent to a flow of only $3 \mathrm{~g}$ daily. This result supported the earlier observations of Heald (195I) and of Weller \& Gray (1954), who found from rumen studies in sheep receiving roughage diets that only $\mathrm{I}-8 \mathrm{~g}$ of starch flowed onwards from the rumen each day. Evidently very little $\alpha$-linked glucose is available for hydrolysis in the small intestine of ruminants fed on roughage diets. In cellulose and hemicellulose the glucose units are joined by a $\beta$-linkage and are not degraded by mammalian enzymes.

In recent years the feeding of cattle, and to a lesser extent of sheep, on all-concentrate diets, rich in starch, has become an established farming practice. On such diets, it is possible that relatively large amounts of starch may escape rumen fermentation. If so, or if substantial amounts of new starch were synthesized and stored in micro-organisms to be passed on to lower sections of the alimentary tract for digestion, this would provide the ruminant with a useful source of glucose. Blaxter (1962) has shown that absorbed glucose is used with a high efficiency for both maintenance and lipogenesis by the ruminant.

The study now described was designed to examine quantitatively the digestion of diets of concentrates, principally barley, and of hay in various sections of the gut of sheep. The animals were fitted with simple or re-entrant cannulas in the abomasum, duodenum or terminal ileum. A subsequent paper (Topps, Kay, Goodall, Whitelaw \& Reid, I968) describes similar work with young steers. These experiments show that very little starch passes to the abomasum and intestines under our conditions. The results agree with the recent findings of MacRae \& Armstrong (1966) but conflict with those of Tucker, Little, Mitchell, Hayes \& Karr (1966) and with those of Porter \& Singleton (1966).

\section{EXPERIMENTAL}

Animals. Seven Scottish Blackface ewes were used. All except one (Annie) were about 3 years old and their weights ranged from 30 to $46 \mathrm{~kg}$. Annie was 8 years old. Each sheep was fitted with an ebonite rumen cannula and all had previously been used for experimental work. Two of the ewes (Maud and Annie) had re-entrant cannulas fitted into the first part of the duodenum (Hogan \& Phillipson, I960) and two others (Ingrid and Joanna) had them fitted into the terminal part of the ileum (Bruce et al. I966); the design of the cannulas is described by Ash (I962a). Two other sheep (Bunty and Ester) had an ebonite cannula of $12 \mathrm{~mm}$ internal diameter fitted into the fundus of the abomasum. These cannulas were closed by a combined cap and core which prevented solid material settling in the barrel between sampling periods. The seventh animal (Fiona) was fitted with re-entrant cannulas in the anterior part of the abomasum (Ash, 1962b). All surgery was performed under general anaesthesia and was completed at least 2 months before the first experiment began.

Diets. Two diets were used: milled and pelleted grass hay, and pelleted concentrates. The concentrates consisted of $(\mathrm{g} / \mathrm{kg})$ : barley (grain with husk), 850; soya-bean meal, 
75; white fish meal, $3^{6}$; molasses, I I ; limestone, I3; dicalcium phosphate, 9 ; sodium chloride, 6 ; ferrous sulphate, 0.3 ; copper sulphate, 0.02; cobalt sulphate, 0.002 ; vitamin A, 6300 i.u./kg; vitamin D, 1500 i.u. $/ \mathrm{kg}$. The composition and apparent digestibility of the diets are shown in Table $\mathrm{I}$.

Table 1 . Composition of the diets $(\mathrm{g} / \mathrm{1} \mathrm{\textrm {o }} \mathrm{g}$ food $)$ and their digestibility

\begin{tabular}{|c|c|c|c|c|c|c|}
\hline & Water & Cellulose & $\begin{array}{c}\text { Total } \\
\text { nitrogen }\end{array}$ & Starch $A^{*}$ & Starch E† & $\begin{array}{c}\text { Digestibility } \\
\text { of dry } \\
\text { matter }(\%)\end{array}$ \\
\hline $\begin{array}{l}\text { Period I : } \\
\text { Concentrate } \\
\text { Hay }\end{array}$ & $\begin{array}{l}14 \cdot 2 \\
13 \cdot 0\end{array}$ & $\begin{array}{r}5 \cdot 5 \\
36 \cdot I\end{array}$ & $\begin{array}{l}2 \cdot 6 \\
1 \cdot 2\end{array}$ & $\begin{array}{r}45.9 \\
6.6\end{array}$ & $\begin{array}{r}46 \cdot 1 \\
4 \cdot 2\end{array}$ & $\begin{array}{r}79 \cdot 9 \\
46 \cdot 6\end{array}$ \\
\hline Period 2: & & & & & & \\
\hline Concentrate & $15 \cdot 3$ & 4.7 & $2 \cdot 4$ & $45 \cdot 5$ & $49^{\circ} \circ$ & $8 \mathrm{I} \cdot 7$ \\
\hline Hay & 14.5 & $35 \cdot 8$ & $I \cdot I$ & $7 \cdot 2$ & 3.9 & $49 \cdot 9$ \\
\hline $\begin{array}{l}\text { Period 3: } \\
\quad \text { Concentrate }\end{array}$ & $14 \%$ & $5 \cdot 5$ & $2 \cdot 7$ & $45 \cdot I$ & $46 \cdot 7$ & $83 \cdot 6$ \\
\hline $\begin{array}{l}\text { Period 4: } \\
\text { Hay }\end{array}$ & $9 \cdot 2$ & $3 I^{\circ} \circ$ & $I \cdot 6$ & $6 \cdot 5$ & $4 \cdot \mathrm{I}$ & $6 x \cdot 8$ \\
\hline
\end{tabular}

The concentrate and hay diets had a mean sugar content of $4 \cdot 1$ and $3 \cdot 1 \%$ respectively.

* Determined by the anthrone method (Clegg, 1956).

$\dagger$ Determined by an enzymic method (MacRae \& Armstrong, 1966).

Table 2. Plan of the experiment, with the sequence and duration of giving the diets to the sheep and the times of collection of samples

Period and starting date

I (7 Oct. 1965)

2 (20 Dec. 1965)

$3(7$ Feb. 1966)

4 (15 Apr. 1966)

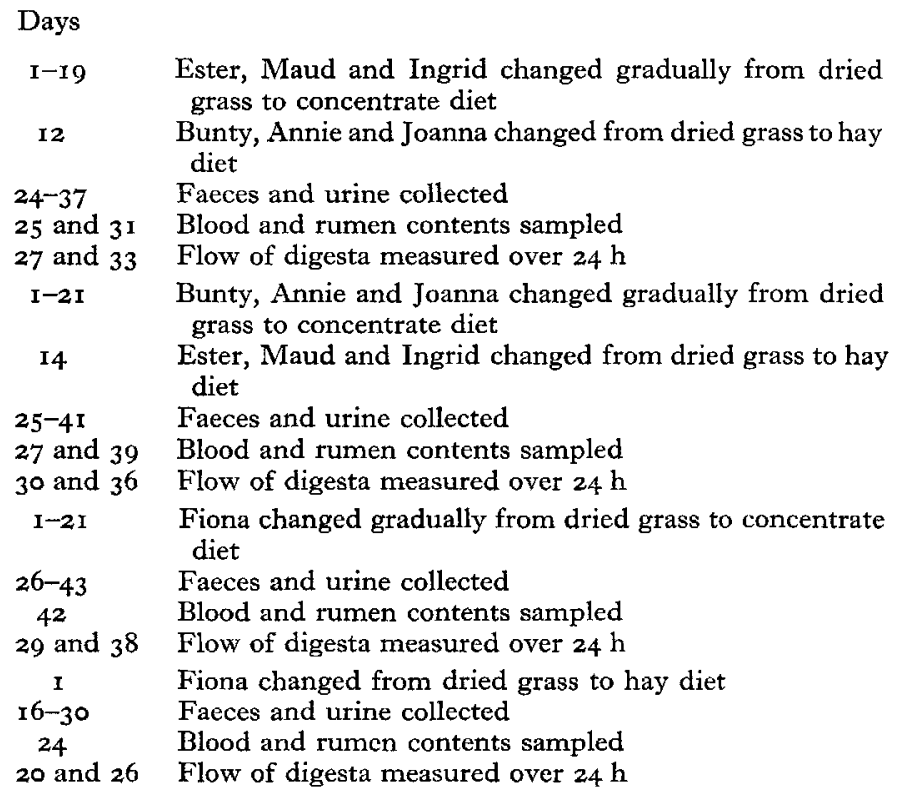

Feeding and sampling. The main part of the work was undertaken with six sheep and was followed by experiments with a seventh sheep, Fiona, to obtain corroborative results. The six sheep were paired according to type of cannulation and one of each pair was allocated to two groups of three animals. For the first half of the main experi- 
ment one group was given the concentrate diet and the other the hay diet; the dietary treatments were then interchanged. A plan of the whole experiment is shown in Table 2.

During experimental periods the sheep were housed in metal metabolism cages (Duthie, 1959) which allowed faeces and urine to be collected separately. Water was freely available and the mean voluntary intake was measured over I4- or I5-day $_{5}$ periods. The daily ration was either $85^{\circ} \mathrm{g}$ hay cubes or $65^{\circ} \mathrm{g}$ concentrate cubes, and these amounts supplied about 1700 and about $1900 \mathrm{kcal}$ of digestible energy respectively. Usually the full ration was consumed but any uneaten food was collected and weighed daily. The food was divided equally into two meals given at 09.00 and $\mathbf{I} 6.00 \mathrm{~h}$. At these times $3 \mathrm{~g}$ of paper impregnated with chromium sesquioxide were inserted via the cannula into the rumen of each sheep to serve as an indigestible reference substance. This supplied $\mathrm{I} \cdot 85 \mathrm{~g}$ of chromium sesquioxide $\left(\mathrm{Cr}_{2} \mathrm{O}_{3}\right)$ daily.

The flow of digesta through the duodenum or ileum of the sheep fitted with reentrant cannulas was recorded and a representative sample was taken by the technique described by Bruce et al. (1966). Two $24 \mathrm{~h}$ collections, separated by an interval of 6 days, were made on each diet. At the same time $30 \mathrm{ml}$ samples of digesta were withdrawn at hourly intervals from the abomasal cannulas of Ester and Bunty and were pooled to make a sample representative of the $24 \mathrm{~h}$. Digesta collected on an earlier occasion was used to restore the volume of digesta being returned to the animals with re-entrant cannulas, but this proved impracticable with Ester and Bunty. The samples were frozen by solid carbon dioxide during collection and subsequently stored at $-20^{\circ}$ until analysed. The $\mathrm{pH}$ of samples of digesta was measured with a Cambridge $\mathrm{pH}$ meter at $2 \mathrm{~h}$ intervals. The behaviour of each sheep was recorded during the collection periods by noting at $\mathrm{I}_{5} \mathrm{~min}$ intervals whether or not she was ruminating.

Food intake and faecal output were recorded for a 12 -day period, which included the two digesta collection days, and a representative sample of faeces was taken for analysis. One or two days before each $24 \mathrm{~h}$ collection blood and rumen samples were withdrawn from the sheep immediately before the morning feed and $2.5 \mathrm{~h}$ later. Previous measurements had shown that, with both diets, the $\mathrm{pH}$ of the rumen contents reached a minimum about $2.5 \mathrm{~h}$ after feeding and this was assumed to correspond to maximal concentration of volatile fatty acids (VFA). About $5 \mathrm{ml}$ of blood were withdrawn from the jugular vein into heparinized tubes and immediately analysed for blood glucose. Approximately $100 \mathrm{ml}$ of rumen contents were obtained by suction from varying depths of the rumen and strained through gauze into a centrifuge tube kept in iced water. The solid material obtained by straining and any excess sample were returned to the rumen with the aid of a little water. The strained rumen liquor was centrifuged at $\mathrm{I} 800 \mathrm{~g}$ for $\mathrm{I} 0 \mathrm{~min}$ and $20 \mathrm{ml}$ of the supernatant liquid were acidified with $\mathrm{I} \mathrm{ml}$ of $10 \mathrm{~N}-\mathrm{H}_{2} \mathrm{SO}_{4}$ and stored at $0^{\circ}$ for determination of VFA.

Chemical analysis. Food, digesta and faeces were dried at $105^{\circ}$ for $48 \mathrm{~h}$; they were then ashed at $570^{\circ}$ and the weights of dry matter and organic matter calculated. Chromium sesquioxide was determined in weighed samples of ash of the faeces and digesta by the procedure of Christian \& Coup (1954). Nitrogen in the fresh samples was determined by the macro-Kjeldahl method. 
Freeze-dried samples of digesta and oven-dried samples of food and faeces were used in the following analyses. Cellulose was measured by the method of Crampton \& Maynard (1938). Calorific values were measured in an adiabatic bomb calorimeter (A. Gallenkamp and Co. Ltd, London). The 'starch' content of the samples was measured both by the 'anthrone' method (Clegg, 1956) and by the enzymic method of MacRae $\&$ Armstrong (1966). The latter determination measures $\alpha$-linked glucose polymers. The material was hydrolysed enzymically with a preparation with mixed amylase activity obtained from Aspergillus niger fermentation broths (Agidex; Glaxo Research $\mathrm{Ltd}$ ) and the glucose formed was determined by the glucose oxidase method of Huggett \& Nixon (I957), using o-dianisidine as an oxygen acceptor.

Blood glucose levels were determined by the same glucose oxidase method. The VFA were steam-distilled from the acidified rumen liquor and the distillate was titrated against standard $\mathrm{NaOH}$, under $\mathrm{CO}_{2}$-free conditions, to give the total concentration of VFA. The proportions of acetic, propionic and butyric acids were determined by the gas chromatographic technique of James \& Martin (1952).

\section{RESULTS}

Appetite. On two occasions whilst receiving the hay diet Ingrid's ileal cannula became blocked overnight with food particles. When this happened she refused her morning feed but after removal of the blockage she began to eat again within a few hours. Throughout this period, however, Ingrid failed to eat her full rations. Joanna and occasionally Annie refused part of the concentrate ration, though for no evident reason. With these exceptions, the animals ate their full rations promptly, generally taking about $20 \mathrm{~min}$ to consume a meal of hay cubes, and $5 \mathrm{~min}$ for a meal of concentrates.

Water intake. With the exception of Ester, the sheep drank about as much water on the concentrate diet, $1620 \mathrm{ml} / 24 \mathrm{~h} \pm 620 \mathrm{sD}$, as on the hay diet, $143 \circ \mathrm{ml} / 24 \mathrm{~h} \pm 370 \mathrm{sD}$. Ester drank much more, $5780 \mathrm{ml} / 24 \mathrm{~h}$ on the concentrate ration and $2670 \mathrm{ml} / 24 \mathrm{~h}$ on the hay ration, but the reason for this was not apparent.

Body-weight. The weights of the sheep remained fairly constant except that Ester and Annie lost from 3 to $6 \mathrm{~kg}$ when given the concentrate diet, and Ingrid lost a similar amount on the hay. All seven sheep remained in approximate nitrogen balance on each diet.

Rumination. The time devoted to rumination, averaged for seven sheep over $2 \mathrm{~h}$ periods during the $24 \mathrm{~h}$ collections, and the average hourly flow of duodenal and ileal contents are shown in Fig. I. As noted previously (Harris \& Phillipson, I962), the flow of duodenal digesta tended to be highest during the period between midnight and midday when most rumination occurred. There was no consistent diurnal pattern of ileal flow. The sheep spent an average of $4.8 \mathrm{~h}$ ruminating daily when given the hay but only $2 \cdot 0 \mathrm{~h}$ when given the concentrates. On the concentrate diet, rumination tended to occur for only a few minutes at a time and boluses were chewed in a more brief and desultory manner than when hay was given.

Flow of digesta. The flow of digesta recorded over the $24 \mathrm{~h}$ periods for five sheep, the 

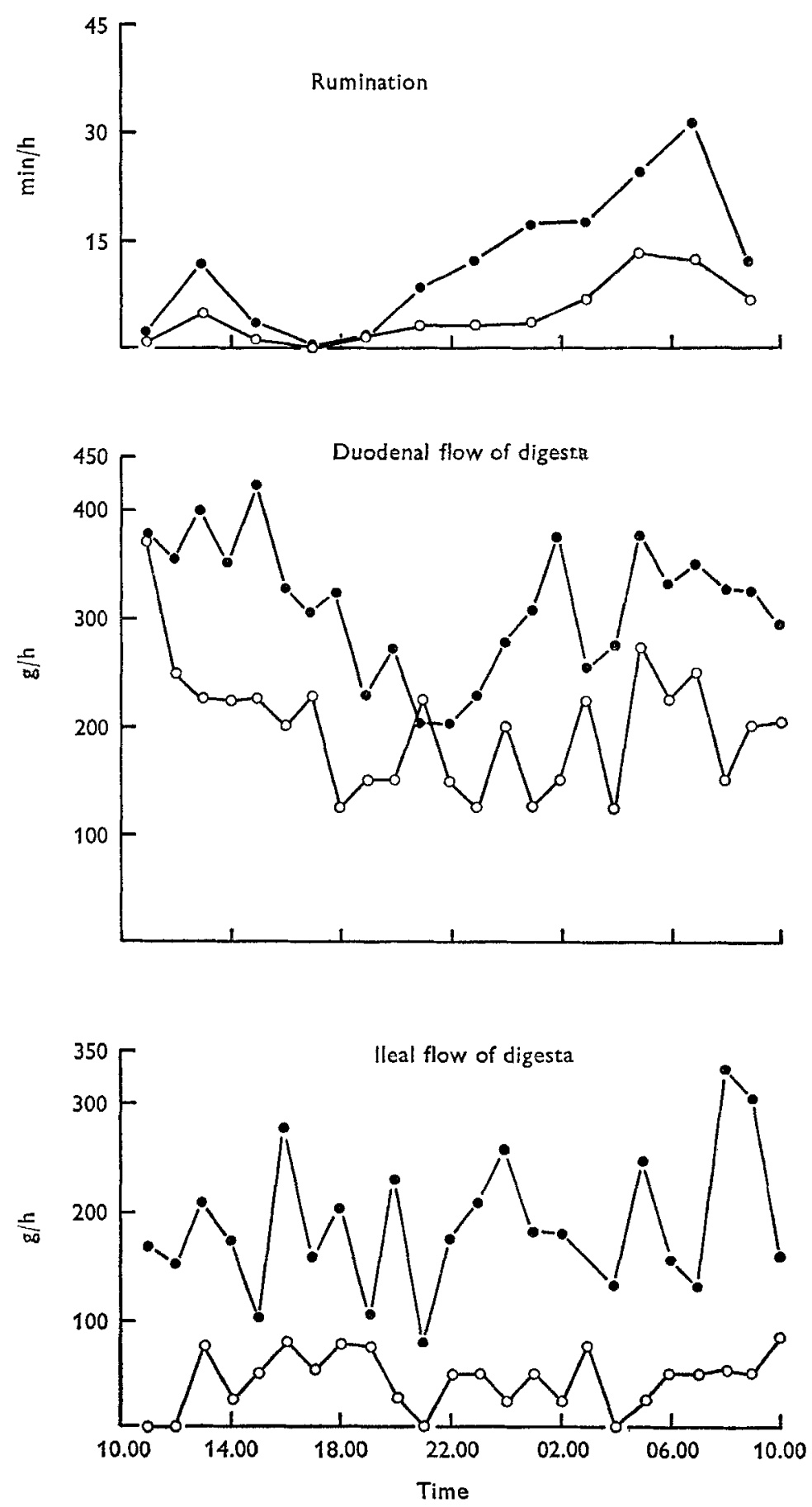

Fig. 1. Diurnal patterns of rumination and of digesta flow. The rations were given as two equal meals at 09.00 and $16.00 \mathrm{~h}$. Each point is the mean value for either seven sheep (rumination) or two (digesta flow). $O$, sheep given concentrate ration; 9 , sheep given hay ration. 
$\mathrm{Cr}_{2} \mathrm{O}_{3}$ content of these digesta, and the calculated flow of digesta required to give $100 \%$ recovery of the $\mathrm{Cr}_{2} \mathrm{O}_{3}$ given daily, are shown in Table 3 . Mean daily faecal output and calculated daily flows of digesta through the abomasum of Bunty and of Ester are also given. The weight of $\mathrm{Cr}_{2} \mathrm{O}_{3}$ passing through the re-entrant cannulas

Table 3. Digesta flow (values for two 24 h collections) and faecal output, before and after adjustment for $100 \%$ recovery of chromium sesquioxide, and the amount of chromium sesquioxide recovered $(g / 24 h)$ in seven sheep receiving two diets

\begin{tabular}{|c|c|c|c|c|c|c|c|}
\hline \multirow[b]{2}{*}{ Sheep } & \multirow[b]{2}{*}{ Cannula } & \multicolumn{3}{|c|}{ Digesta } & \multicolumn{3}{|c|}{ Faeces } \\
\hline & & $\begin{array}{l}\text { Measured } \\
\text { flow }\end{array}$ & $\begin{array}{l}\mathrm{Cr}_{2} \mathrm{O}_{3} \\
\text { recovered }\end{array}$ & $\begin{array}{l}\text { Adjusted } \\
\text { flow }\end{array}$ & $\begin{array}{l}\text { Measured } \\
\text { output }\end{array}$ & $\begin{array}{l}\mathrm{Cr}_{2} \mathrm{O}_{3} \\
\text { recovered }\end{array}$ & $\begin{array}{l}\text { Adjusted } \\
\text { output }\end{array}$ \\
\hline \multicolumn{8}{|c|}{ Concentrate diet } \\
\hline Fiona & Abomasal & $\begin{array}{l}5195 \\
528 I\end{array}$ & $\begin{array}{l}x \cdot 45 \\
I .89\end{array}$ & $\begin{array}{l}6650 \\
5170\end{array}$ & 194 & $x \cdot 59$ & 225 \\
\hline Bunty & & - & - & $\begin{array}{l}5200 \\
6430\end{array}$ & 142 & $\mathbf{I} \cdot 74$ & I $5 \mathbf{I}$ \\
\hline Ester & & - & - & $\begin{array}{l}5570 \\
5 \times 60\end{array}$ & 215 & $\mathbf{I} \cdot 77$ & 226 \\
\hline Annie & Duodenal & $\begin{array}{l}5379 \\
3657\end{array}$ & $\begin{array}{l}I \cdot 7 \mathrm{I} \\
I \cdot 15\end{array}$ & $\begin{array}{l}5820 \\
5880\end{array}$ & 143 & $1 \cdot 52$ & 174 \\
\hline Maud & & $\begin{array}{l}5684 \\
4519\end{array}$ & $\begin{array}{l}x \cdot 62 \\
x \cdot 37\end{array}$ & $\begin{array}{l}6500 \\
6100\end{array}$ & 208 & I'77 & $2 \times 8$ \\
\hline Joanna & Ileal & $\begin{array}{r}964 \\
1032\end{array}$ & $\begin{array}{l}0.94 \\
I .96\end{array}$ & $\begin{array}{r}\text { I900 } \\
975\end{array}$ & 164 & $x \cdot 76$ & I 72 \\
\hline Ingrid & & $\begin{array}{r}\text { I4I3 } \\
914\end{array}$ & $\begin{array}{c}* \\
\mathbf{x} 30\end{array}$ & 1300 & 234 & $I \cdot 60$ & $27 \mathrm{I}$ \\
\hline \multicolumn{8}{|c|}{ Hay diet } \\
\hline Fiona & Abomasal & $\begin{array}{r}9069 \\
10455\end{array}$ & $\begin{array}{l}1 \cdot 60 \\
x \cdot 74\end{array}$ & $\begin{array}{l}10520 \\
11082\end{array}$ & 764 & $1 \cdot 82$ & 779 \\
\hline Bunty & & - & - & $\begin{array}{l}9180 \\
8770\end{array}$ & 725 & $x \cdot 76$ & 761 \\
\hline Ester & & - & - & $\begin{array}{l}7240 \\
7810\end{array}$ & 791 & $I \cdot 8 I$ & 807 \\
\hline Annie & Duodenal & $\begin{array}{l}6989 \\
8352\end{array}$ & $\begin{array}{l}\mathbf{1} \cdot 60 \\
1 \cdot 58\end{array}$ & $\begin{array}{l}8090 \\
9779\end{array}$ & 700 & $r \cdot 80$ & 721 \\
\hline Maud & & $\begin{array}{l}7207 \\
7533\end{array}$ & $\begin{array}{l}I \cdot 48 \\
I \cdot 83\end{array}$ & $\begin{array}{l}9009 \\
7616\end{array}$ & 775 & $r \cdot 83$ & 783 \\
\hline Joanna & Ileal & $\begin{array}{l}4^{813} \\
4037\end{array}$ & $\begin{array}{l}I \cdot 7 I \\
I \cdot 29\end{array}$ & $\begin{array}{l}5207 \\
5780\end{array}$ & 776 & $\mathbf{I} \cdot 80$ & 799 \\
\hline Ingrid & & $\begin{array}{l}4588 \\
4810\end{array}$ & $\begin{array}{l}2 \cdot 36 \\
1 \cdot 56\end{array}$ & $\begin{array}{l}3596 \\
5600\end{array}$ & $66_{3}$ & $x \cdot 52$ & 809 \\
\hline
\end{tabular}

Table 4. Mean values and standard deviations for $p H$ of digesta collected over four $24 \mathrm{~h}$ periods from three pairs of sheep receiving two diets

\begin{tabular}{lccc}
\multicolumn{1}{c}{ Diet } & $\begin{array}{c}\text { Abomasal } \\
\text { digesta }\end{array}$ & $\begin{array}{c}\text { Duodenal } \\
\text { digesta }\end{array}$ & $\begin{array}{c}\text { Ileal } \\
\text { digesta }\end{array}$ \\
Concentrate & $2 \cdot 35 \pm 0.33$ & $2 \cdot 80 \pm 0.43$ & $7.73 \pm 0.23$ \\
Hay & $2 \cdot 69 \pm 0.45$ & $2.46 \pm 0.39$ & $7.93 \pm 0.18$
\end{tabular}




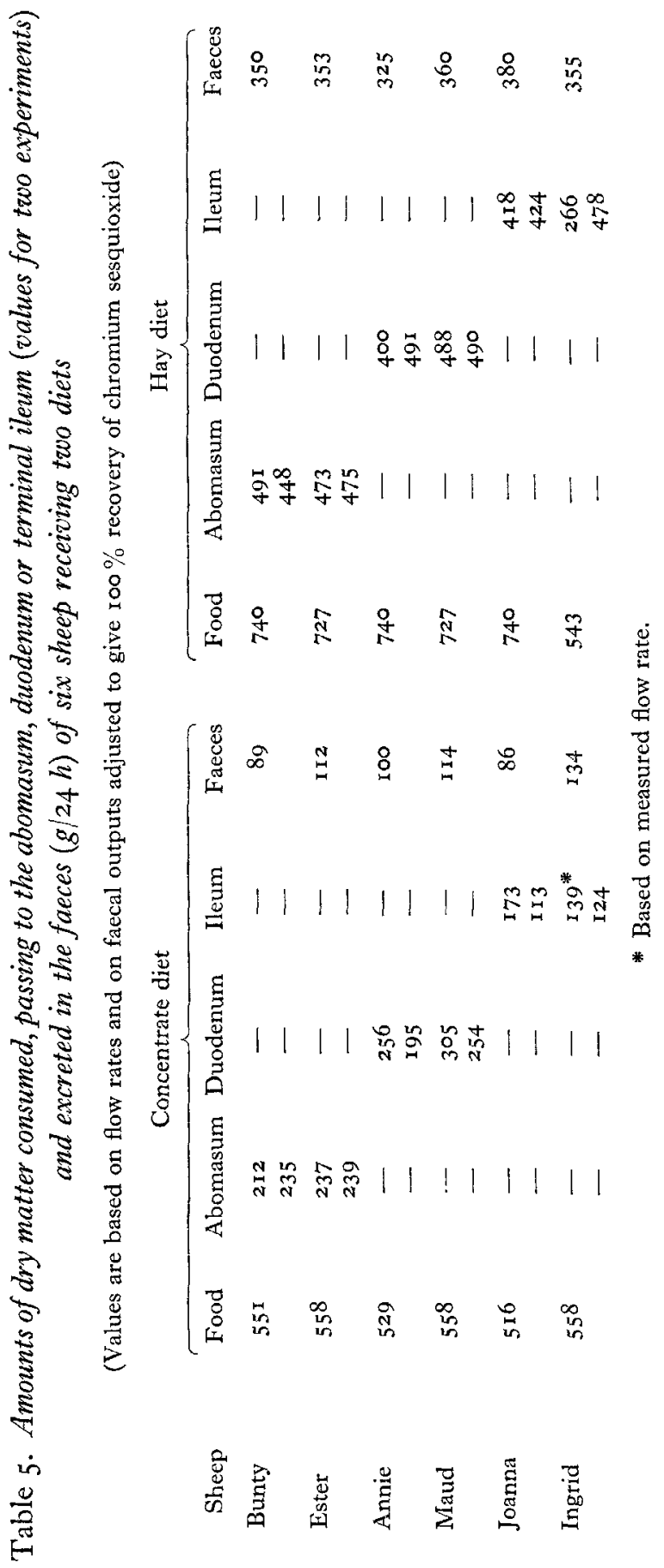


during the $24 \mathrm{~h}$ collection periods was usually less than the amount introduced into the rumen, $\mathrm{x} \cdot 85 \mathrm{~g}$ daily. As a result, the recorded duodenal flow averaged only $83 \%$ of the calculated $24 \mathrm{~h}$ flow, the ileal flow $86 \%$ and the faecal output $93 \%$.

Abomasal and duodenal flows were about $\mathrm{I} \cdot 5$ times greater and ileal flow was nearly 4 times greater on the hay diet than on the concentrate diet.
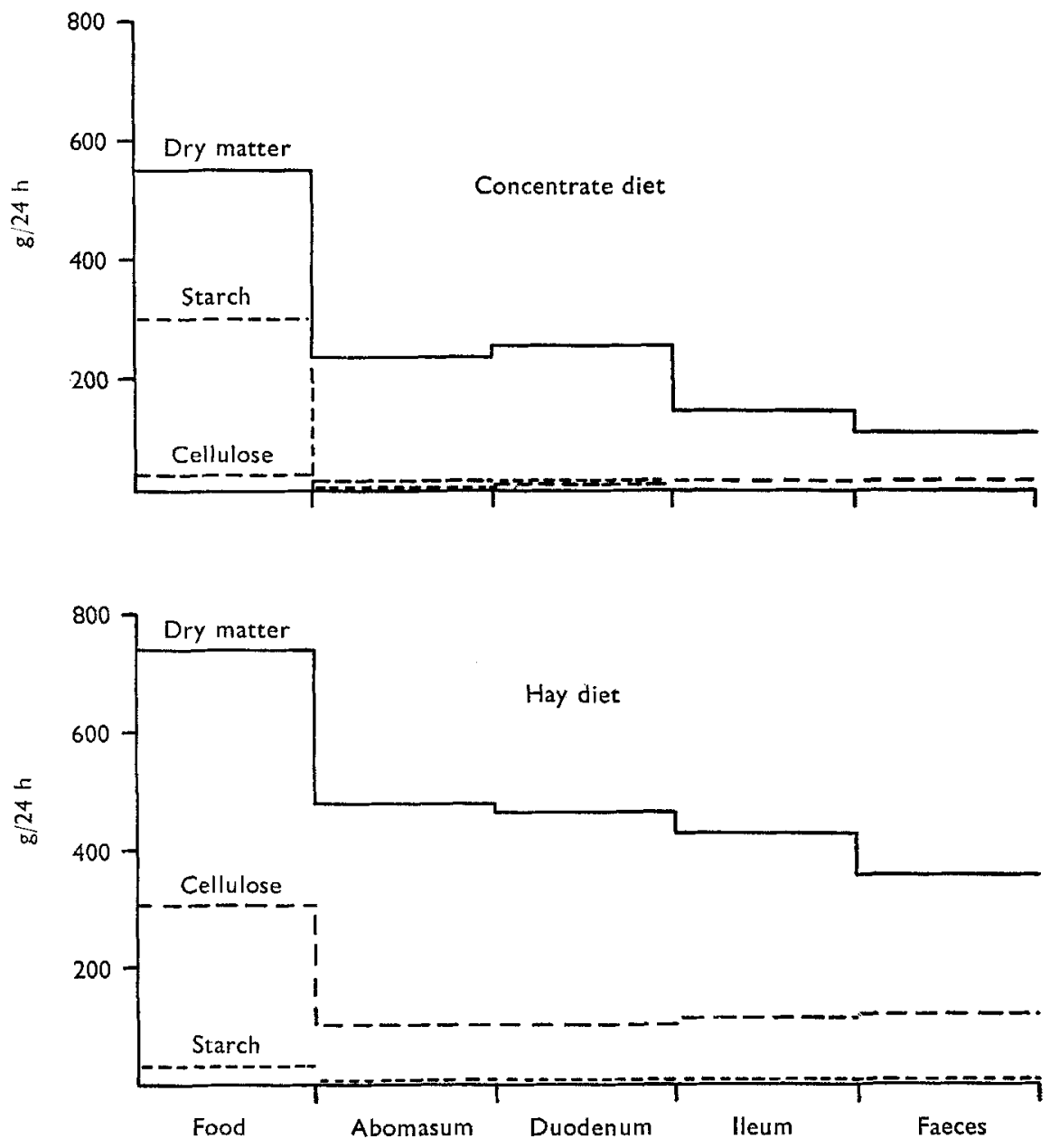

Fig. 2. Mean amounts of dry matter, starch and cellulose in the food (six sheep), in the abomasal, duodenal and ileal digesta (two sheep each) and in the faeces (six sheep).

$p H$ of digesta. The mean $\mathrm{pH}$ values of the digesta are given in Table 4 . The $\mathrm{pH}$ of the abomasal digesta, and also of the ileal digesta, tended to be higher with the hay diet than with the concentrates, whilst a converse trend was found with material flowing through the duodenum, but none of these differences achieved statistical significance.

Amounts of various constituents passing through the digestive tract. Tables 5-10 give the quantities of dry matter, starch (two tables), cellulose, nitrogen and energy found 
in the food, digesta and faeces of the six sheep given each diet. The corresponding results for Fiona are shown in Table I 1 . The mean values for dry matter, starch and cellulose are shown diagrammatically in Fig. 2.

The results of the main experiment showed that, of the apparently digestible dry matter of the hay diet, some $67 \%$ (range $65-72 \%$ ) disappeared from the stomach (throughout this paper the term 'stomach' refers to reticulo-rumen, omasum and abomasum, and the term 'forestomach' refers to reticulo-rumen and omasum), about $22 \%$ from the small intestine (by difference between the sheep with duodenal or abomasal cannulas and Joanna with ileal cannulas), and about I I from the large intestine. Values for the second sheep with ileal cannulas, Ingrid, unfortunately had to be disregarded since her variable food intake and faecal output did not permit comparisons of digesta flows measured over $24 \mathrm{~h}$ with mean food and faeces values. Fiona received a much more digestible hay ration and in her case $46 \%$ of the digestible dry matter disappeared from her forestomach.

When the concentrate diet was given, $69 \%$ (range $63-7 \mathrm{r} \%$ ) of the digestible dry matter disappeared from the stomach, $17 \%$ from the small intestine and $14 \%$ in the large intestine. The latter value is again based only on Joanna; the apparent changes in dry matter in digesta passing through Ingrid's large intestine suggest that ileal flow had been underestimated. Values for Fiona indicated the loss of $64 \%$ of digestible dry matter from the forestomach.

The corresponding values for organic matter (dry matter minus ash) indicated that on the concentrate and hay diets, respectively, 76 and $83 \%$ of the apparently digestible organic matter disappeared from the stomach, 19 and $7 \%$ from the small intestine and 5 and $10 \%$ from the large intestine.

The results shown in Tables 6 and 7 for starch show that of the $298 \mathrm{~g}$ starch supplied daily in the concentrate diet only $6-35 \mathrm{~g}$ reached the abomasum or duodenum. The amounts passing from the stomach on the hay diet were smaller still. With both diets, most, if not all, of this starch seemed to be hydrolysed in the small intestine, although somewhat contrary and inexplicable results were obtained with Joanna when her ileal digesta were analysed for starch by the enzymic method. In general, however, reasonably close agreement was obtained between the values for starch content obtained by the two analytical methods. The anthrone method usually gave slightly higher results than the enzymic method. No free glucose was present in the digesta or faeces.

Table 8 shows that some $28 \%$ of the small amount of cellulose contained in the concentrate ration, and $59 \%$ of the large amount in the hay ration, were digested. With both diets cellulose digestion seemed confined to the stomach.

On a net basis there was a considerable addition of total nitrogen to the stomach contents of the sheep when they were given hay cubes (Table 9). Although the dietary $\mathrm{N}$ content of the concentrate ration was approximately $50 \%$ greater than that of the hay cubes, the amounts of nitrogen passing to the small intestine were similar for the two diets. Some $8 \mathrm{~g}$ of this nitrogen disappeared from the small intestine, and a further $\mathrm{I}-2 \mathrm{~g}$ from the large intestine.

The pattern of energy disappearance along the digestive tract paralleled that of the dry-matter losses (Table ro). When the concentrate ration was given, about $72 \%$ of 
Vol. 22

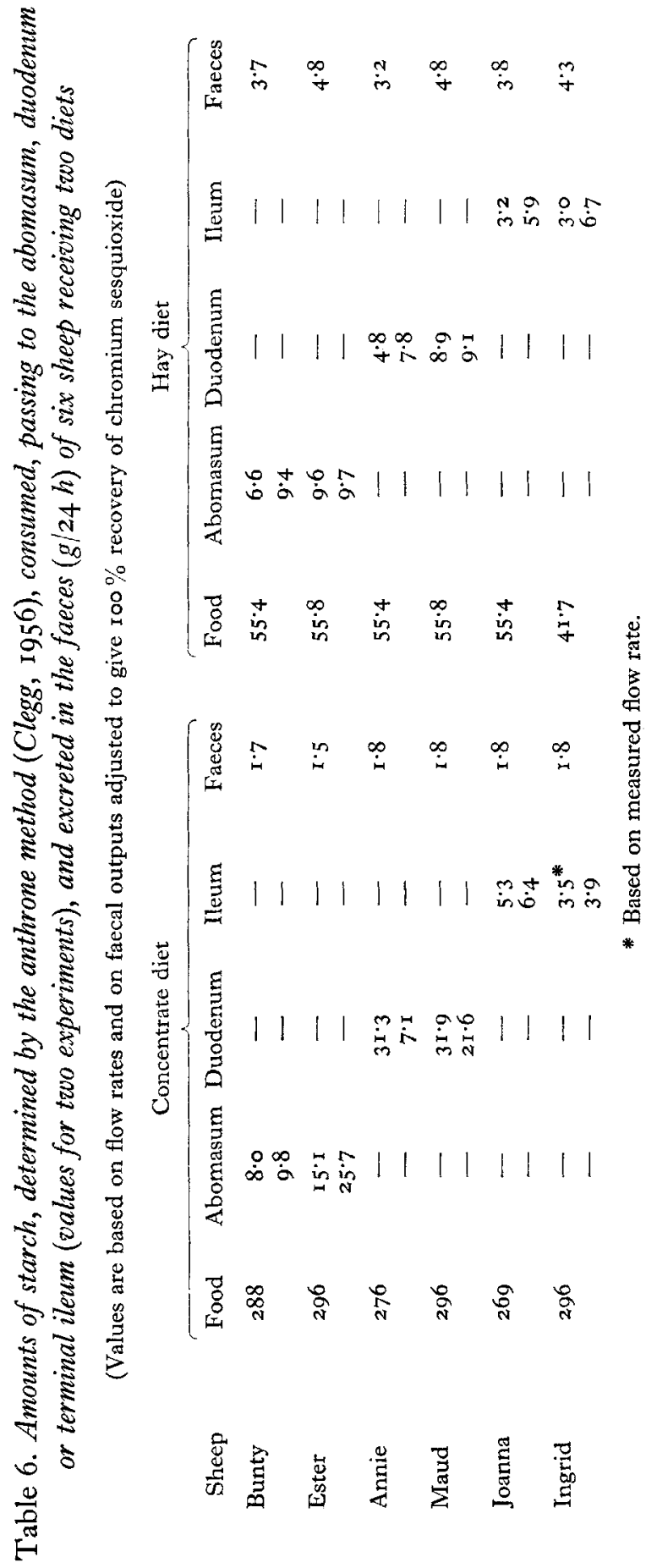




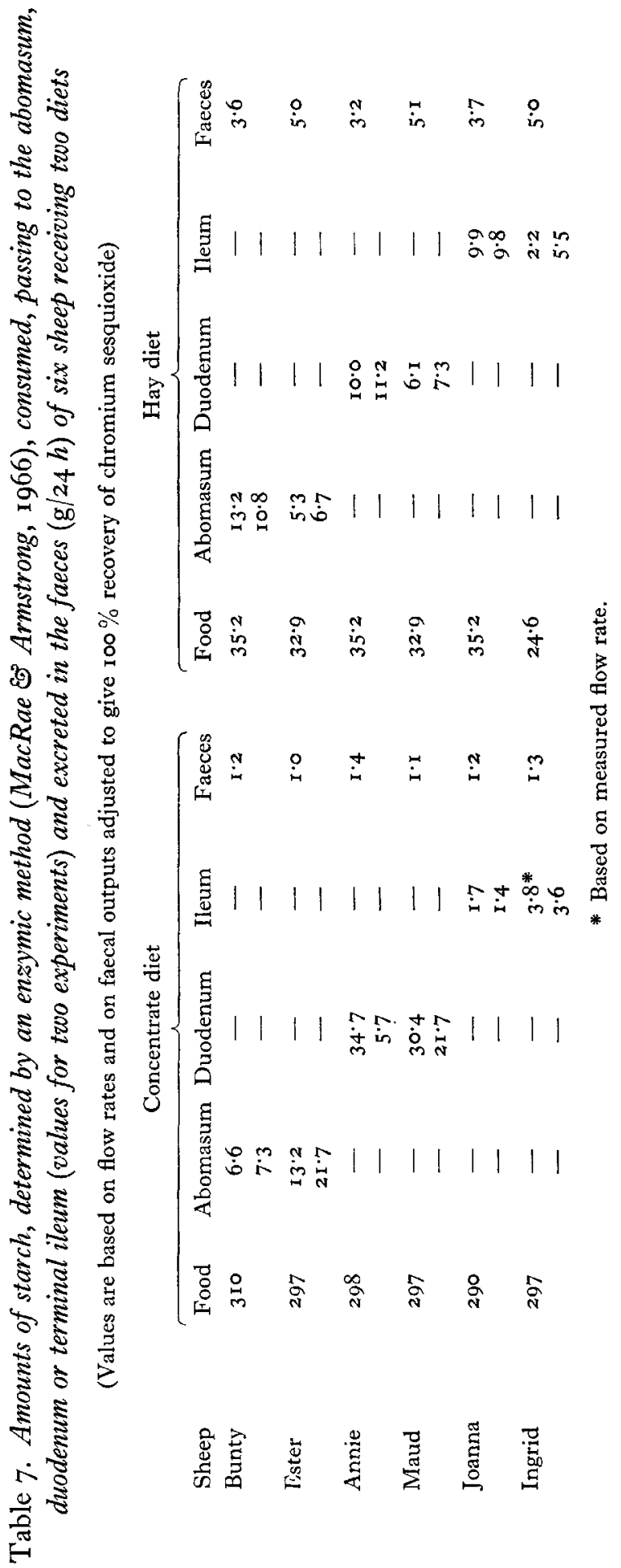


Vol. 22

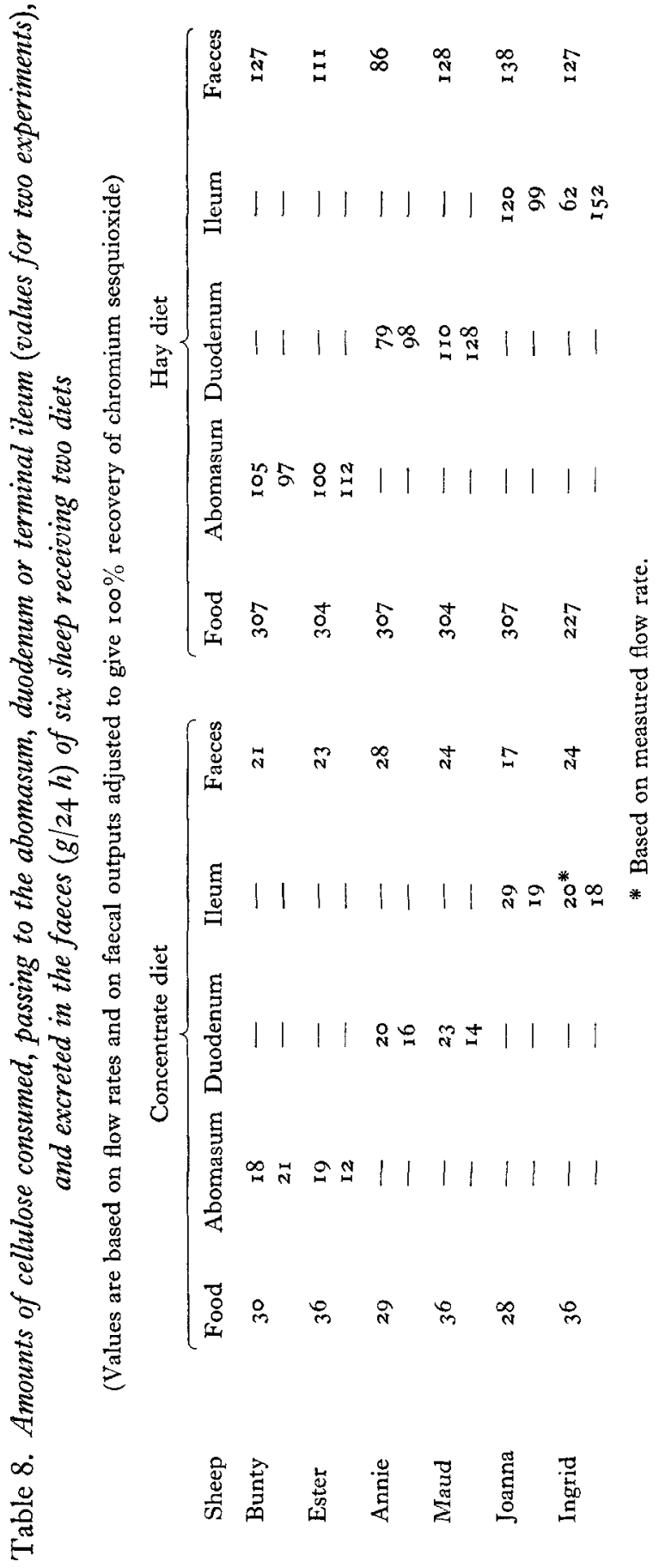




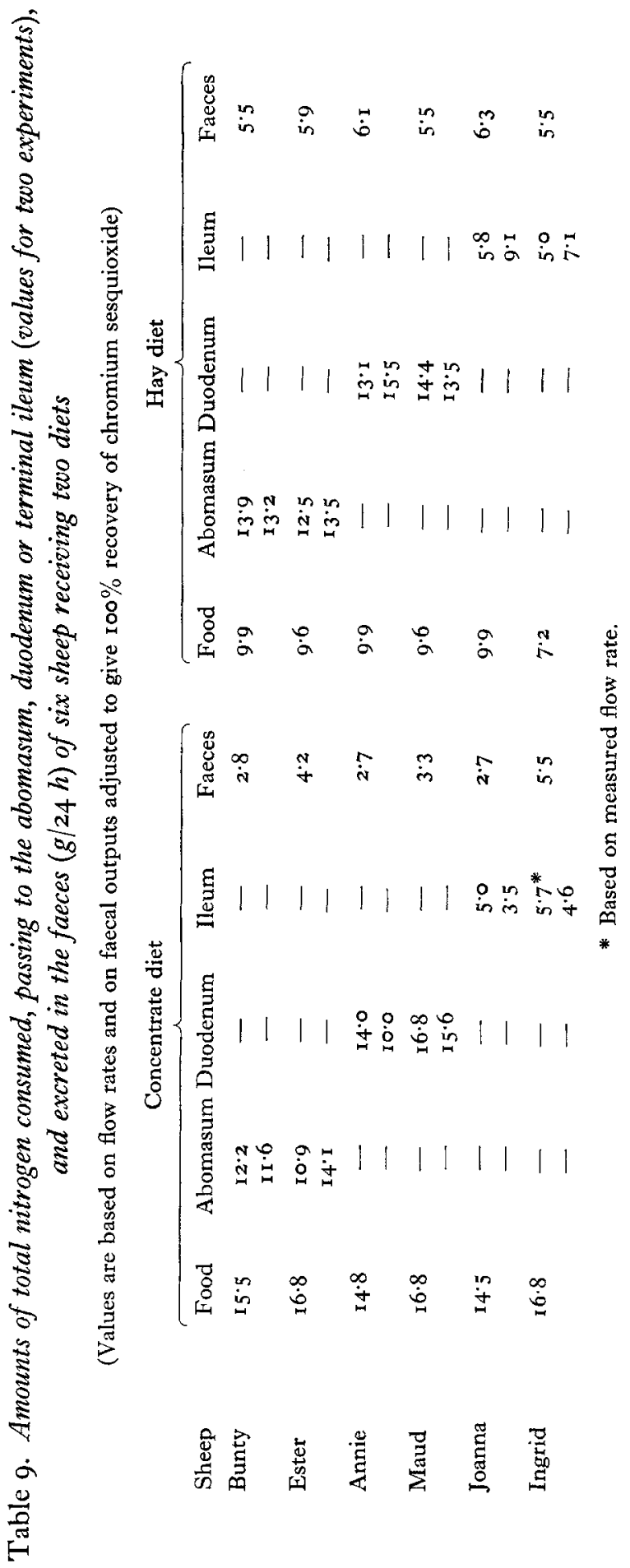


Vol. 22

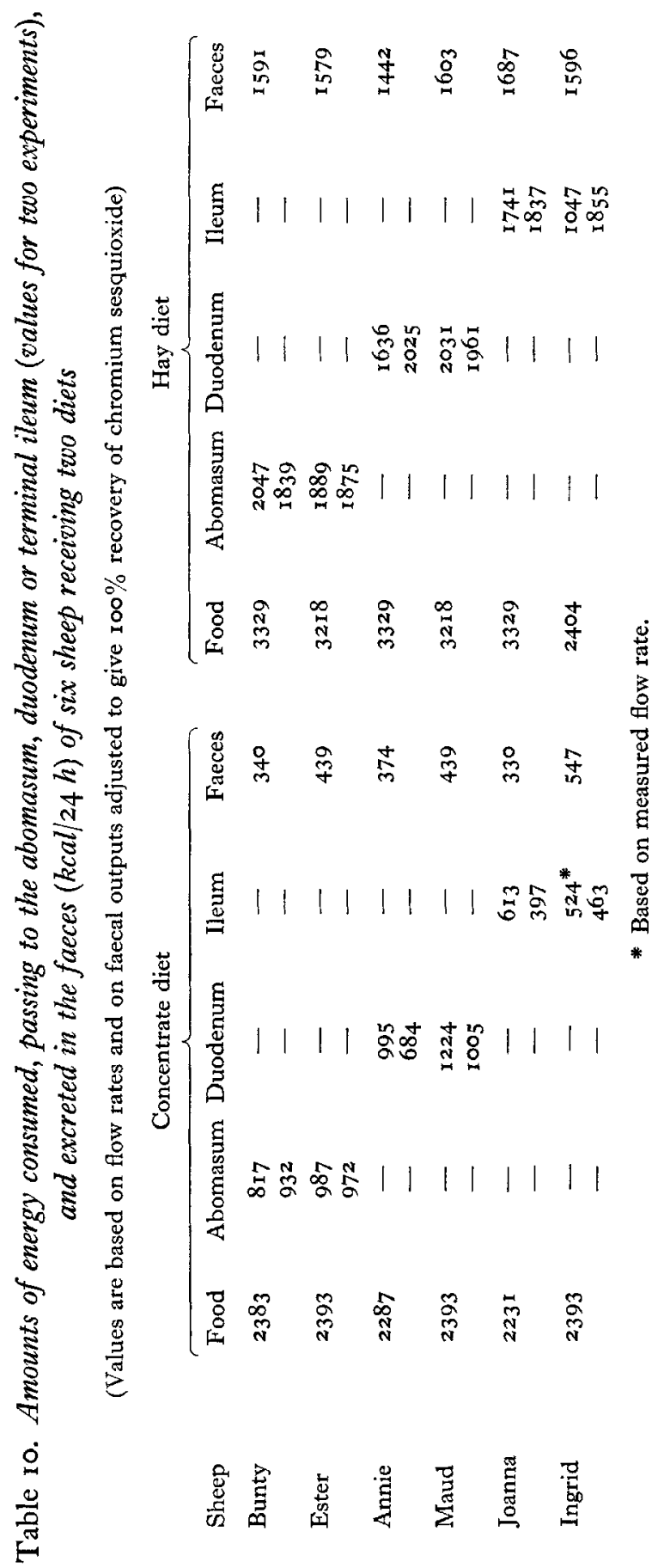


the digestible energy was accounted for by breakdown processes in the stomach (the corresponding value for Fiona was $67 \%$ ). Of the remainder $23 \%$ was digested in the small intestine and $5 \%$ in the large intestine. When hay cubes were given the

Table I. Amounts of dry matter, starch, cellulose and total nitrogen $(g / 24 h)$ and of energy ( $k$ call $24 h$ ) consumed, passing to the abomasum (values for two experiments) and excreted in the faeces of a sheep receiving two diets

(Values are based on flow rates and on faecal outputs of sheep Fiona, adjusted to give $100 \%$ recovery of chromium sesquioxide)

\begin{tabular}{|c|c|c|c|c|c|c|}
\hline \multirow[b]{2}{*}{ Constituent } & \multicolumn{3}{|c|}{ Concentrate diet } & \multicolumn{3}{|c|}{ Hay diet } \\
\hline & Food & Abomasum & Faeces & Food & Abomasum & Faeces \\
\hline Dry matter & $55^{6}$ & $\begin{array}{l}264 \\
287\end{array}$ & 106 & 772 & $\begin{array}{l}540 \\
567\end{array}$ & 300 \\
\hline Starch A* & 293 & $\begin{array}{r}9 \cdot 5 \\
28 \cdot 3\end{array}$ & $2 \cdot 3$ & $55^{\circ} 4$ & $\begin{array}{r}8 \cdot 6 \\
11=0\end{array}$ & $4 * 4$ \\
\hline Starch E† & 335 & $\begin{array}{l}14.0 \\
40 \cdot 4\end{array}$ & $1 \cdot 4$ & $34 \%$ & $\begin{array}{l}12.7 \\
15.6\end{array}$ & $3 \cdot 3$ \\
\hline Cellulose & $3 I$ & $\begin{array}{l}14 \\
17\end{array}$ & 16 & 240 & $\begin{array}{l}114 \\
121\end{array}$ & 84 \\
\hline Nitrogen & $17 \cdot 2$ & $\begin{array}{l}15 \cdot 6 \\
17 \cdot 7\end{array}$ & $8 \cdot 4$ & 13.5 & $\begin{array}{l}18 \cdot 6 \\
20 \cdot 0\end{array}$ & $6 \cdot 6$ \\
\hline Energy & 2389 & $\begin{array}{r}977 \\
\times 175\end{array}$ & 425 & 3444 & $\begin{array}{l}2167 \\
2284\end{array}$ & I 347 \\
\hline
\end{tabular}

* Determined by the anthrone method (Clegg, 1956).

+ Determined by an enzymic method (MacRae \& Armstrong, 1966).

Table 12. Mean values and standard deviations for blood glucose concentrations, and concentrations and molar proportions of volatile fatty acids $(V F A)$ in the rumen, of seven sheep receiving two diets

\begin{tabular}{|c|c|c|c|c|}
\hline & \multicolumn{2}{|c|}{ Concentrate diet } & \multicolumn{2}{|c|}{ Hay diet } \\
\hline & $\begin{array}{l}\text { Before } \\
\text { feeding* }\end{array}$ & $\begin{array}{c}\text { After } \\
\text { feedingt }\end{array}$ & $\begin{array}{c}\text { Before } \\
\text { feeding* }\end{array}$ & $\begin{array}{c}\text { After } \\
\text { feeding } †\end{array}$ \\
\hline Blood glucose $(\mathrm{mg} / \mathrm{I} 00 \mathrm{ml})$ & $40 \cdot 6 \pm 3 \cdot 1$ & $44 \cdot 1 \pm 2 \cdot 9$ & $4 I \cdot 0 \pm 4 \cdot 6$ & $42 \cdot I \pm 3 \cdot 8$ \\
\hline Total VFA (m-equiv./1.) & $54 \cdot 7 \pm 12 \cdot 7$ & $94.6 \pm 13.0$ & $56 \cdot 0 \pm 9 \cdot 7$ & $79 \cdot 7 \pm 8 \cdot 9$ \\
\hline Acetic acid $(\%)$ & $48 \cdot 6 \pm 8 \cdot 7$ & $44 \cdot 5 \pm 4 \cdot 9$ & $65 \cdot 8 \pm 4 \cdot 3$ & $6_{3} \cdot 3 \pm 2 \cdot 8$ \\
\hline Propionic acid $(\%)$ & $24 \cdot 7 \pm 6 \cdot 6$ & $34 \cdot 6 \pm 7 \cdot 8$ & $22 \cdot 3 \pm 2 \cdot 5$ & $24 \cdot 6 \pm 2 \cdot 7$ \\
\hline Butyric and higher acids ( $\%$ ) & $26 \cdot 7 \pm 4 \cdot 4$ & $20 \cdot 9 \pm 4 \cdot 5$ & II.9 $\pm 4 \cdot 7$ & $12 \cdot 1 \pm 1 \cdot 5$ \\
\hline
\end{tabular}

mean values for disappearance of digestible energy were $8 \mathrm{I} \%$ in the stomach, $7 \%$ in the small intestine and $12 \%$ in the large intestine. In Fiona a much lower value, of $58 \%$ for disappearance of digestible energy in the forestomach, was observed.

Concentrations of blood glucose and of VFA in the rumen. Table 12 shows the blood glucose concentrations and the VFA concentrations and molar proportions in the 
seven sheep on each diet. Diet had little or no effect on concentrations of glucose. When, $2 \frac{1}{2} \mathrm{~h}$ after feeding, the $\mathrm{pH}$ of the rumen contents had been shown to reach a minimum, the concentration of total VFA and the proportion of propionate were considerably greater on the concentrate diet than on the hay cubes. At both sampling times, the proportion of acetate in the rumen of concentrate-fed sheep was considerably less and that of butyrate and higher acids was considerably more than that found in the sheep receiving hay cubes.

\section{DISCUSSION}

The main aim of the study was to see if large quantities of starch can escape rumen fermentation and pass to the small intestine of sheep when they are given a diet rich in starch. The results clearly show that only small amounts, ranging from 6 to $35 \mathrm{~g}$ daily, reached the abomasum or duodenum. At most this represents only $6 \%$ of the dietary intake of $298 \mathrm{~g}$ daily. This finding is consistent with the results of MacRae 8 Armstrong (1966), who reported finding only $17-22 \mathrm{~g}$ of $\alpha$-linked glucose polymers in the duodenal contents of sheep receiving a diet of $200 \mathrm{~g}$ hay and $700 \mathrm{~g}$ rolled barley daily. On the other hand, it is at variance with the results contained in a brief report by Tucker et al. (1966). These workers showed that with diets containing 40,60 or $80 \%$ ground maize, and which supplied daily 326,462 or $580 \mathrm{~g}$ starch to wether sheep, between I 20 and I $44 \mathrm{~g}$ starch passed to the abomasum. Porter \& Singleton (1966) also found that about a third of the starch consumed by sheep receiving a ration of $1300 \mathrm{~g}$ hay and $200 \mathrm{~g}$ concentrate reached the intestine. The work of Wright, Grainger \& Marco (I966) again indicates that under some conditions appreciable amounts of starch may escape fermentation in the rumen. These workers analysed the contents of the abomasum of sheep killed at various intervals after a meal of concentrates rich in maize. Starch, as a percentage of dry matter, was high enough $3 \mathrm{~h}$ after feeding to suggest that substantial amounts may pass to the intestines, though with no measure of the digestibility of dry matter in the rumen or of flow through the abomasum it is not possible to assess this amount quantitatively. It is difficult to postulate a reason for these discrepancies between results from different centres. It is conceivable that differences in the fermentation of maize starch and barley starch, or differences in levels of feeding, methods of sampling and analysis could be responsible, but none of these factors offers a very plausible explanation. Nevertheless, at present it may be concluded that only small amounts of starch are available for hydrolysis in the small intestine of sheep given restricted amounts of concentrate diet composed principally of barley.

Although small in quantity this starch may make a useful contribution to the glucose available to the animal. Armstrong (1965) summarized the evidence available on glucose metabolism in sheep. The requirement of a non-pregnant sheep is estimated to be $89 \mathrm{~g}$ daily. Armstrong suggested that, since little glucose is available for absorption from the intestine when roughage diets are given, most of this essential metabolite must be derived from the propionate formed in the rumen. Our results suggest that propionate must remain the principal source of glucose, even when con- 
centrate diets containing large amounts of starch are given. Our next paper (Topps et al. I968) further considers this important aspect of metabolism.

The hay cubes supplied the sheep with only about $34 \mathrm{~g}$ of starch daily. Although very little reached the abomasum or duodenum, this amount was greater relative to intake than when concentrates were given, suggesting that much of it may have been of microbial origin. Unfortunately, the analytical methods used did not differentiate food starch from microbial starch. The amount of starch in the duodenal contents of sheep given hay cubes agreed well with the values of Heald (I95I), Weller \& Gray (1954) and Porter \& Singleton (1965).

Although the two procedures for determining starch usually gave similar results, those obtained by the anthrone method were often a little higher than those by the enzymic method. This may be explained by the presence of certain mucopolysaccharides which gave a slight colour reaction with anthrone. Mucin bought as a chemical (Koch-Light) gave a colour reaction equivalent to $8 \%$ that of potato starch (British Drug Houses Ltd).

The extent of the disappearance of other dietary constituents in various parts of the gut is consistent with the findings of earlier workers. The fact that $90 \%$ or more of the cellulose digested disappeared in the stomach agrees with the results of Porter \& Singleton (1965) and of Bruce et al. (1966). The low overall digestibility of the small amount of cellulose in the concentrate ration was probably due to a depression of the cellulolytic flora caused by a preponderance of starch in the diet (Belasco, 1956).

The disappearance of approximately $70 \%$ of the digestible dry matter in the sheep's stomach agrees with the findings of Hogan \& Phillipson (I960). The fact that more than half of the post-ruminal digestion of the dry and organic matter of the diets occurred in the small intestine illustrates the importance of enzymic digestion in the ruminant. The substances digested included nearly all of the starch and most of the nitrogenous compounds flowing from the abomasum.

When the sheep were given the concentrate diet the amount of nitrogen passing through the abomasum was similar to the amount consumed, but when hay was given there was a substantial net addition of nitrogen to the stomach contents. Similar changes in the nitrogen content of digesta have been recorded by Harris \& Phillipson (1962) and by Clarke et al. (1966). This effect is of great importance to the ruminant in helping it to overcome a deficiency of dietary nitrogen.

The disappearance of energy along the digestive tract parallels that of dry and organic matter. It is interesting to note that quite a large amount of energy, $209 \mathrm{kcal} / 24 \mathrm{~h}$, was lost by food residues passing through the large intestine when hay was given, whereas only $88 \mathrm{kcal} / 24 \mathrm{~h}$ were lost when concentrates were given. It is not clear what substances were being fermented since there was little digestion of cellulose and nitrogenous compounds. Possibly, hemicelluloses of the diet and mucopolysaccharides secreted into the small intestine were yielding to bacterial attack.

Previous measurements of the flow of digesta through the duodenum have shown it to be related to both the amount of food eaten and its roughage content. Hogan (1964) estimated the duodenal flow of sheep to be $7-$ I I $1 . / 24 \mathrm{~h}$ when 700-800 g hay were given and $13^{-29} 1 . / 24 \mathrm{~h}$ when $1700 \mathrm{~g}$ were given. Phillips \& Dyck (r964) found the flow to be 
increased by raising the straw content of the ration given. These two effects adequately explain the differences in volume of flow of duodenal digesta between the hay cubes and the concentrate diet. Flow of digesta through the ileum was still more closely related to the intake of indigestible matter, as observed previously by Goodall \& Kay (I965).

The values for the flow and composition of digesta that were obtained by withdrawing frequent small samples from an abomasal cannula were very similar to those obtained by the more tedious procedure of measuring and sampling flow through reentrant cannulas placed in the first part of the duodenum. As sheep with re-entrant cannulas are also the more difficult to prepare and manage, this suggests that in some instances abomasal sampling may provide a convenient alternative.

With both diets the concentration of glucose in jugular blood showed little change after feeding. Annison, Hill \& Lewis (1957) suggested that the lack of a response of glucose concentration in portal blood to feeding indicates that very little carbohydrate is absorbed as glucose from the alimentary tract. If this suggestion is valid, the smallness of the increase in blood sugar after the concentrate ration has been given may be regarded as supporting the evidence that little starch reaches the intestine.

The patterns of ruminal VFA associated with the two diets were typical for a hay diet (Bath \& Rook, 1963) and for a diet high in starchy concentrates (Balch \& Rowland, 1957). Blaxter (I962) has shown that this pattern of VFA, in particular the proportion of acetate, is closely related to the net availability of the metabolizable energy of the diet for lipogenesis. Our view on the significance of this relationship for concentrate diets would need to be re-examined if appreciable amounts of starch were digested in the intestine to give glucose which is used with a high efficiency for lipogenesis. Our results indicate that any consequences of intestinal digestion of glucose are likely to be small.

One of us (J.H.T.) gratefully acknowledges receipt of a special grant from the Underwood Fund of the Agricultural Research Council whilst on sabbatical leave from the University College of Rhodesia. It is a pleasure to thank Miss M. Reid and Mr W. Dunbar for technical assistance and Mr R. S. Reid for gas chromatographic analysis.

\section{REFERENCES}

Annison, E. F., Hill, K. J. \& Lewis, D. (1957). Biochem. F. 66, 592.

Armstrong, D. G. (1965). In Physiology of Digestion in the Ruminant, p. 272. [R. W. Dougherty, editor.] London: Butterworths.

Ash, R. W. (1962a). Anim. Prod. 4, 309.

Ash, R. W. (1962b). F. Physiol., Lond. 164, 4 P.

Balch, D. A. \& Rowland, S. J. (I957). Br. F. Nutr. II, 288.

Bath, I. H. \& Rook, J. A. F. (1963). F. agric. Sci., Camb. 6r, 34 I.

Belasco, I. J. (1956). F. Anim. Sci. 15, 496.

Blaxter, K. L. (1962). The Energy Metabolism of Ruminants. London: Hutchinson.

Bruce, J., Goodall, E. D., Kay, R. N. B., Phillipson, A. T. \& Vowles, L. E. (1966). Proc. R. Soc. B r66, 46.

Christian, K. R. \& Coup, M. R. (r954). N.Z. Fl Sci. Tech. A 36, 328.

Clarke, E. M. W., Ellinger, G. M. \& Phillipson, A. T. (1966). Proc. R. Soc. B 166, 63.

Clegg, K. M. (1956). F. Sci. Fd Agric. 7, 40.

Crampton, E. W. \& Maynard, L. A. (1938). F. Nutr. 15, 383.

Duthie, I. F. (1959). Lab. Pract. 8, 408. 
Goodall, E. D. \& Kay, R. N. B. (1965). F. Physiol., Lond. 176, I 2.

Harris, L. E. \& Phillipson, A. T. (1962). Anim. Prod. 4, 97.

Heald, P. J. (195I). Br. F. Nutr. 5, 84.

Hogan, J. P. (1964). Aust. F. agric. Res. 15, 384.

Hogan, J. P. \& Phillipson, A. T. (1960). Br. F. Nutr. 14, r47.

Huggett, A. St G. \& Nixon, D. A. (1957). Lancet ii, 368.

James, A. T. \& Martin, A. J. P. (1952). Biochem. F. 50, 679.

MacRae, J. C. \& Armstrong, D. G. (I966). Proc. Nutr. Soc. 25, xxxiii.

Phillips, G. D. \& Dyck, G. W. (1964). Can. F. Anim. Sci. 44, 220.

Phillipson, A. T. (1952). F. Physiol., Lond. r16, 84.

Porter, P. \& Singleton, A. G. (1965). Biochem. F. 96, $59 P$.

Porter, P. \& Singleton, A. G. (1966). F. Physiol., Lond. 186, 145P.

Ridges, A. P. \& Singleton, A. G. (1962). F. Physiol., Lond. r6r, I.

Sineshchekov, A. D. (editor) (1953). Fiziologiya pitaniya sel'skokhozyă̌stvennȳkh zhivotnȳkh. Moscow: Sel'khozgiz. (The nutritional physiology of farm animals. English translation 1964. National Lending Library for Science and Technology, Boston Spa, Yorkshire.)

Topps, J. H., Kay, R. N. B., Goodall, E. D., Whitelaw, F. G. \& Reid, R. S. (1968). Br. F. Nutr. 22, 28I.

Tucker, R. E., Little, C. O., Mitchell, G. E., Hayes, B. W. \& Karr, M. R. (Ig66). F. Anim. Sci. 25, $9 \mathrm{II}$.

Weller, R. A. \& Gray, F. V. (1954). F. exp. Biol. 31, 40.

Wright, P. L., Grainger, R. B. \& Marco, G. J. (1966). F. Nutr. 89, 24 I. 